\title{
Deneysel Diyabet Oluşturulan Sıçanlarda Kalp ve İskelet Kası Nrf2 Yapımı ve Oksidatif Stres Üzerine Melatoninin Etkisinin İncelenmesi
}

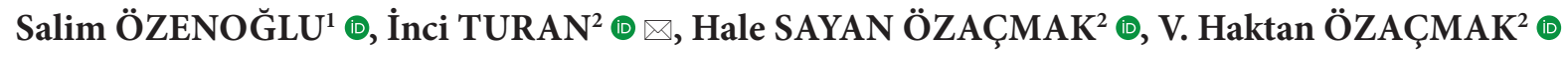 \\ ${ }^{1}$ Zonguldak Bülent Ecevit Üniversitesi, Sağlık Bilimleri Enstitüsü, Fizyoloji Programı, Zonguldak, Türkiye \\ ${ }^{2}$ Zonguldak Bülent Ecevit Üniversitesi, Tip Fakültesi, Fizyoloji Anabilim Dalı, Zonguldak, Türkiye
}

Bu makaleye yapılacak atıf: Özenoğlu S, Turan İ, Sayan Özaçmak H, Özaçmak VH. Deneysel Diyabet Oluşturulan Sıçanlarda Kalp ve İskelet Kası Nrf2 Yapımı ve Oksidatif Stres

Üzerine Melatoninin Etkisinin İncelenmesi. Türk Diyab Obez 2020;1: 46-53.

\begin{abstract}
ÖZET
Amaç: Diabetes mellitus (DM) kronik hiperglisemi ile karakterize metabolik bir hastalıktır. Bu çalışmanın amacı, melatoninin DM'li sıçanlarda iskelet kası ve kalp kası üzerindeki etkilerini değerlendirmektir.

Gereç ve Yöntemler: 36 erkek Wistar albino rat kontrol grubu, kontrol + melatonin grubu, Diyabet grubu, Diyabet + melatonin grubu olarak 4 gruba ayrıldı. Melatonin (10 mg / kg, ip) tedavisi dört hafta süreyle uygulandı. Malondialdehit (MDA) seviyeleri ve indirgenmiş glutatyon seviyeleri (GSH) ile Nrf2 ve tiyoredoksin (TRX) seviyeleri değerlendirildi.

Bulgular: Diyabetik grubun iskelet ve kalp kası MDA düzeyleri kontrol gruplarına göre yüksek bulunurken, melatonin tedavisi ile bu değer anlamlı düzeyde azalmıştır ( $<0,05)$. İskelet kası GSH seviyesi melatonin tedavili diyabet grubunda, diyabet grubuna göre yüksek bulunmuştur. Diyabet grubunda iskelet kası Nrf2 düzeyleri kontrol gruplarına göre azalmıştır. Bu azalış melatonin uygulaması ile kontrol değerlerine yükselmiştir. Kalp kası Nrf2 düzeyleri diyabet grubunda düşük görülmesine rağmen bu farklıllk anlamlı değildir. İskelet kası TRX seviyelerinde gruplar arasında farklılık saptanmamıştır. Kalp kası TRX seviyeleri diyabetik grupta düşük bulunurken melatonin tedavisi ile yükselmiştir ( $\mathrm{p}<0,05)$.

Sonuç: Çalışmamızın sonuçları melatonin tedavisinin hipergliseminin oluşturduğu oksidatif stresi iskelet kasında Nrf2 yolağı ile kalp kasında ise TRX yolağı ile azaltabileceğini göstermektedir.
\end{abstract}

Anahtar Sözcükler: Diabetes mellitüs, Melatonin, Nrf2, Oksidatif stres

\section{The Effects of Melatonin on Nrf2 Expression and Oxidative Stress in Heart Muscle and Skeletal Muscle in Rats with Experimental Diabetes}

\begin{abstract}
Aim: Diabetes mellitus (DM) is a metabolic disease characterized by chronic hyperglycemia. The goal of this study was to assess the effects of melatonin on skeletal muscle and heart muscle in rats with DM.

Material and Methods: 36 male Wistar albino rats were divided into 4 groups as control group, control+melatonin group, Diabetes group, Diabetes+melatonin group. Melatonin $(10 \mathrm{mg} / \mathrm{kg}$, ip) treatment was administered for four weeks. Malondialdehyde (MDA) level, reduced glutathione levels (GSH), Nrf2 and thioredoxin (TRX) levels were assessed.

Results: Skeletal and heart muscle MDA levels of the diabetic group were increased than the control groups and melatonin treatment was remarkably decreased this value. $(\mathrm{p}<0.05)$. Skeletal muscle GSH levels in the melatonin treated diabetic group was significantly higher than the diabetic group. In the diabetic group, skeletal muscle Nrf2 levels were found lower than control groups. This value increased to control levels with Melatonin treatment. Nrf2 levels of heart muscle in the diabetes group was found to be decreased, but
\end{abstract}

ORCID: Salim Özenoğlu / 0000-0002-1911-269X, İnci Turan / 0000-0003-2211-3914, Hale Sayan Özaçmak / 0000-0002-3564-0468, V. Haktan Özaçmak / 0000-0003-2651-8353 
it was not statistically significant. There was no differences between the groups in skeletal muscle in TRX levels. In the diabetes group, heart muscle TRX levels were lower than control groups and melatonin treatment increased this level $(\mathrm{p}<0.05)$.

Conclusion: Our results showed that melatonin treatment can reduce the oxidative stress induced with hyperglycemia by Nrf 2 pathway in skeletal muscle and by TRX pathway in cardiac muscle.

Key Words: Diabetes mellitus, Melatonin, Nrf2, Oxidative stress

\section{GİRIŞ}

Diabetes Mellitus (DM) kronik hiperglisemi ile seyreden yaygın bir hastalıktır. Kronik hiperglisemi serbest oksijen radikallerinin (SOR) yapımı ile birliktedir ve böbrek, beyin, göz, sinir sistemi, kan damarları, kalp gibi organlarda oksidatif stres artışı ile uzun dönemde patolojik değişiklikler, organ disfonksiyonu ve organ yetmezliklerine neden olmaktadır (1). Yükselmiş kan glukoz seviyesi proinflamatuar sitokinlerin yapımını uyarır, lipit peroksidasyonu ve apoptotik süreci aktive ederek çeşitli diyabet komplikasyonlarına neden olur. İnsan ve deney hayvanlarında oksidatif stresin lipit peroksidasyonu, protein oksidasyonu ve DNA hasarı ile nöronal ölümde santral rol oynadığı saptanmıştır (2).

Artan SOR, DM'un en önemli komplikasyonlarından biri olan diyabetik kardiyomiyopati gelişimine neden olur (3). Kardiyak kontraktilitenin bozulması, artan SOR nedeniyle oluşan mitokondrial disfonksiyon, hücre dışı matrikste biriken ileri glikasyon son ürünleri (AGE) neticesinde diyastolik disfonksiyon ve kalp yetmezliği, anormal hücre metabolizması sonucu zararlı lipid birikimi ve çinko ve bakır gibi gerekli metallerin hemeostazının bozulması diyabetik kardiyomiyopatinin patofizyolojik mekanizmalarını oluşturur (4).

DM kas yapısını da etkilemektedir. Diyabetik miyopati fiziksel aktivite ile kas kitle ve gücünü azaltarak diyabetik komplikasyonların artışına neden olmaktadır. Diyabetik miyopatide kas liflerinin sayısında azalma, atrofi ve kapiller yoğunlukta azalma gözlenmektedir (5). Ayrıca artan oksidatif stres ve inflamatuar cevap insülin direncinin oluşumunda rol alır (6). İskelet kasında hiperinsülinemi, hiperlipidemi, glukokortikoid ve inflamatuar sitokinler gibi çeşitli nedenlerle glukoz dağılımının bozulması SOR yapımının artışı ile sonuçlanmaktadır (7). Normal şartlarda vücuttaki glukozun büyük bir kısmı iskelet kasında metabolize edilir. İskelet kası metabolizmasındaki bozukluklar, vücuttaki glukoz dengesini ve insülin duyarlılığını olumsuz yönde etkiler (8). Bu yüzden diyabetik miyopatinin komorbidite gelişme oranını doğrudan artırdığı düşünülmektedir (9).

Nuclear factor erythroid 2-related factor 2 (Nrf2) redoks duyarlı transkripsiyon faktörüdür ve pek çok antioksidan enzimin ve faz II detoksifikasyon enzimlerinin gen yapımını kontrol eder $(10,11)$. Nrf2 sinyalinin aktivasyonu diyabetin periferal komplikasyonlarının engellenmesinde önemli yere sahiptir $(10,11)$. Nrf2 hücrede indirgenmiş glutatyon (GSH) miktarının kontrolünde ve redoks homeostazisinin korunmasinda önemlidir. Tioredoksin (TRX) ve GSH oksidatif stresle oluşan sitotoksisiteden hücreleri koruyan majör tiyol antioksidanlardır. TRX majör olarak endotel hücreleri tarafından yapılır ve hücreleri oksidatif strese karşı korur. Aynı zamanda TRX hücrelerde hemoksijenaz-1 yapımını da kontrol eder (11).

Melatonin epifiz bezinde triptofan aminoasidinden sentezlenmektedir. Melatoninin yapılan çalışmalar sonucu; antiinflamatuar, antioksidan, antionkostatik ve sirkadyen ritim düzenleme gibi fonksiyonları olduğu belirlenmiştir (12). Ayrıca diyabetle ortaya çıkan komplikasyonları azaltmada etkili olduğu da bildirilmektedir (13). Melatonin uygulamasının diyabetik sıçan retinasında Nrf2 miktarının azalmasını engelleyerek oksidatif stresi azalttığı gösterilmiştir. Diyabette Nrf2 aktivasyonu ile oksidatif stresin engellenmesi son zamanlarda diyabet komplikasyonlarının azaltılmasında yer almaktadır (14).

$\mathrm{Bu}$ bilgiler doğrultusunda bu çalışmanın amacı diyabetik sıçanlarda melatonin uygulamasının iskelet ve kalp kası Nrf2 düzeyleri ile oksidatif stres üzerine etkilerini incelemektir.

\section{GEREÇ ve YÖNTEMLER}

\section{Deney Hayvanları}

Çalışmamızda Zonguldak Bülent Ecevit Üniversitesi Deney Hayvanları Araştırma ve Uygulama Merkezinde üretilen 36 adet Wistar-Albino cinsi erkek sıçanlar kullanıldı. Ağırlıkları 275-470 gram olan sıçanlar; 20-22 ${ }^{\circ} \mathrm{C}$ derece sıcaklıkta, 12 saat aydınlık 12 saat karanlık döngüsünde, çeşme suyu ve $\% 21$ ham protein içeren pelet yemlerle serbest erişimi olacak şekilde uygun laboratuvar koşulları altında tutuldu. Çalışmamıza öncesinde Zonguldak Bülent Ecevit Üniversitesi Hayvan Deneyleri Yerel Etik Kurulu tarafindan onay verildi (Protokol no: 2016-47-06/10).

\section{Grupların Oluşturulması}

Diyabet veya diyabete bağlı komplikasyonlar yüzünden denek kaybedilebileceği ihtimalinden dolayı diyabet grup- 
ları kontrol gruplarına göre 2 denek fazla olacak şekilde oluşturuldu. Deney hayvanlarından rastgele seçilen 20 tanesi deneysel diyabet oluşturmak için ayrıldı. Geriye kalan 16 tane deney hayvanı; 8 adet kontrol, 8 adet kontrol+melatonin olmak üzere rastgele ikiye ayrilarak isimlendirildi. Deneysel diyabet modeli oluşturulabilen 19 hayvan da; 9 adet diyabet, 10 adet diyabet+melatonin olmak üzere iki gruba ayrilarak isimlendirildi.

\section{Diyabet Oluşturulması}

Diyabet modeli oluşturmak için streptozotosin (STZ) (Sigma-Aldrich, St. Louis, MO, ABD), 0,1 M sitrat tamponu $(\mathrm{ph}=4,5)$ içinde hazırlandı. Rastgele seçilen 20 adet sıçana $60 \mathrm{mg} / \mathrm{kg}$ her birine tek doz olacak şekilde intraperitoneal (ip) olarak uygulandı. Diğer sıçanlara aynı miktarda sitrat tamponu ip olarak uyguland. STZ uygulamasindan sonra akut dönemde oluşabilecek hipoglisemiyi engellemek için ilk 48 saat için kafes suluklarına $\% 5$ glukoz çözeltisi konuldu. STZ enjeksiyonundan 72 saat sonra kuyruk venlerinden alınan kan örneklerinden glukometre (lifecheck, Almanya) ile kan şekeri düzeylerine bakıldı. Kan şekeri düzeyi 250 mg/ dl'nin üzerindeki sıçanlar diyabet olarak kabul edildi.

\section{Melatonin Tedavisi}

Melatonin (Sigma-Aldrich, St. Louis, MO, ABD), ip enjeksiyon için \%1 ethanol ve \%0,9 $\mathrm{NaCl}$ içinde çözdürüldü ve stok solüsyon hazırland. Kontrol+melatonin ve diyabet+melatonin gruplarındaki deneklere $10 \mathrm{mg} / \mathrm{kg}$ olmak üzere günlük ip olarak enjekte edildi (14). Diğer deneklere aynı stresi yaşatmak için ip olarak aynı miktarda serum fizyolojik enjeksiyonu yapıldı.

\section{Doku Örneklerinin Alınması}

Tüm sıçanlar, 4 haftalık enjeksiyon uygulamaları bitiminden sonra yüksek doz anestezi (sodyum tiyopental) enjeksiyonuyla feda edildi. Soleus kası izole edilerek çıkarıldı. Kalp dokusu çıarıldı ve kan dokusundan ayrıldı. Alınan örnekler, $-80^{\circ} \mathrm{C}$ 'de iki eşit parçaya ayrılmış halde çalışma yapılacak güne kadar saklandı.

\section{MDA ve GSH Ölçümüi}

Oksidatif stresin sonucu lipit peroksidasyonunun bir göstergesi olan MDA miktarının ölçüldüğü bu yöntemde, alınan soleus kası ve kalp kası dokuları \%10'luk triklorasetik asit eklenerek doku homojenizatöründe homojenize edildi. Homojenize edilen dokular 3000 devirde $15 \mathrm{dk}$ santrifüj edildi. Elde edilen süpernatanın üzerine tiyobarbitürik asit ve butilhidroksitoluen eklenerek tüplerin ağzı kapatıldı ve 15 $\mathrm{dk} 100^{\circ} \mathrm{C}^{\prime}$ de kaynatıld. Elde edilen sivı spektrofotometrede $535 \mathrm{~nm}$ absorbansta okunarak MDA miktarı nmol/g doku olarak bulundu (15).
Endojen bir antioksidan olan GSH miktarı modifiye Ellman metoduna göre çalıșıldı (16). Hazırlanmış olan süpernatanlara $1000 \mu \mathrm{l} \mathrm{0,3} \mathrm{M}$ disodyum hidrojen fosfat (Na2HPO4) eklendi. Sonrasında $125 \mu$ l Ellman reaktifi eklenerek 5-10 dk sonra, spektrofotometrede $412 \mathrm{~nm}$ absorbansta okunarak $\mu \mathrm{mol} / \mathrm{g}$ doku olarak GSH düzeyi belirlenmiştir.

\section{NRF2 ve TRX Düzeylerinin Belirlenmesi}

Doku örnekleri hazırlanan fosfat tampon solüsyonu (PBS) eklenerek doku homojenizatöründe homojenize edildikten sonra $3000 \mathrm{rpm}$ ve $2-8{ }^{\circ} \mathrm{C}$ 'de $20 \mathrm{dk}$ santrifüj edildi. Elde edilen süpernatanlar, Nrf2 (Sun Red Biotechnology, Çin, katalog no: 201-11-5375) ve TRX (Sun Red Biotechnology, Çin, katalog no: 201-11-0445) düzeylerinin belirlenmesi için enzyme-linked immün sorbent assay (ELISA) yöntemi ile analiz edildi.

\section{İstatistiksel Analiz}

Elde edilen veriler ortanca (min-maks) hata olarak verilmiştir. Verilerin değerlendirilmesi için SPSS 22.0 istatistik programı (IBM, ABD) kullanılmıştır. Gruplar arası farklılıkların değerlendirilmesinde Kruskal Wallis testi, grup içindeki farklılıkların değerlendirilmesinde ise Dunn testi kullanılarak karşılaştırma yapılmıştır. İstatistiksel anlamlılık, p değerinin 0,05'ten küçük olduğu değerler için kabul edilmiştir.

\section{BULGULAR}

\section{İskelet ve Kalp Kasının MDA ve GSH Düzeyleri}

Diyabet iskelet kası MDA düzeyini kontrol gruplarına göre yükseltmiştir $(\mathrm{p}=0,005)$. Melatonin uygulaması iskelet kasında yükselen MDA düzeylerini düşürmüştür $(\mathrm{p}=0,009)$ (Tablo 1). Diyabetli grupların kalp kası MDA düzeyi kontrol gruplarına göre yüksek bulunmuştur $(\mathrm{p}=0,001)$. Melatonin uygulaması ise kalp kası MDA düzeylerini azaltmıştır $(\mathrm{p}=0,04)$ (Tablo 1).

İskelet kas dokusu GSH düzeyleri kontrol+melatonin grubunda, kontrol grubundaki değerlere göre yüksek bulunmuştur $(\mathrm{p}=0,001)$. Diyabetli grupların iskelet kası GSH düzeyleri, kontrol+melatonin grubundaki değerlere göre düşük bulunmuştur ( $\mathrm{p}=0,014)$ (Tablo 2). Melatonin tedavisi diyabetli grupların iskelet kası GSH düzeylerinde anlamlı bir farklılık yaratmamıştır. Kontrol+melatonin grubunda kalp kası GSH düzeyleri, kontrol grubuna göre anlamlı derecede yüksek bulunmuştur ( $\mathrm{p}=0,01)$ (Tablo 2).

\section{İskelet ve Kalp Kasının Nrf2 ve TRX Düzeyleri}

Diyabet iskelet kası Nrf2 düzeylerinin kontrol gruplarına göre azalmasına neden olmuştur $(\mathrm{p}=0,006)$. Melatonin 
uygulaması iskelet kası Nrf2 düzeylerini diyabetli gruba göre yükseltmiştir $(\mathrm{p}=0,001)$ (Tablo 3$)$. Diyabet+melatonin grubu kalp kas1 Nrf2 düzeyi, diyabet grubu Nrf2 düzeyine göre anlamlı derecede yüksek bulunmuştur $(\mathrm{p}=0,001)$ (Tablo 3).

İskelet kası TRX düzeyleri melatonin uygulanan gruplarda uygulanmayan gruplara göre daha yüksek olmasına karşın gruplar arasında anlamlı bir fark bulunamamıştır. Kalp kası TRX düzeyleri diyabette kontrol gruplarına göre düşük bulunmuştur $(\mathrm{p}=0,003)$. Melatonin uygulaması ile kalp kasında TRX düzeyleri yükselmiştir ( $\mathrm{p}=0,001)$ (Tablo 4).

\section{TARTISSMA}

Yaptığımız çalışmanın sonuçları; diyabetin iskelet ve kalp kasında oksidan stresi artırırken, melatoninin antioksidan etkisiyle bu durumu tersine çevirdiğini göstermiştir. STZ ile diyabet oluşturulmuş ratların her iki dokusunda oksidan stresin göstergesi olan MDA düzeylerinin arttığ 1 ve melatonin tedavisi ile bu artışın engellendiği gösterilmiştir. GSH seviyesi iskelet kasında diyabetle beraber azalırken melatonin tedavisi anlamlı bir değişiklik yaratmamıştır. Diyabet NRF2 seviyelerinin iskelet kasında azalmasina neden olurken melatonin uygulamasiyla bu

Tablo 1. İskelet ve kalp kası MDA düzeyleri.

\begin{tabular}{|c|c|c|c|c|c|}
\hline & Kontrol & Kontrol+Mel & Diyabet & Diyabet+Mel & $\mathbf{p}$ \\
\hline İskelet Kası MDA nmol/g doku & $\begin{array}{c}56 \\
(53-57)\end{array}$ & $\begin{array}{c}52 \\
(49-54)\end{array}$ & $\begin{array}{l}81,5^{\star} \# \\
(78-84)\end{array}$ & $\begin{array}{c}58 \# \& \\
(57-62)\end{array}$ & 0,001 \\
\hline Kalp Kası MDA nmol/g doku & $\begin{array}{c}36 \\
(33-37)\end{array}$ & $\begin{array}{c}43 \\
(39-44) \\
\end{array}$ & $\begin{array}{l}76,5^{*} \# \\
(66-78)\end{array}$ & $\begin{array}{c}62,5 * \& \\
(59-65)\end{array}$ & 0,001 \\
\hline
\end{tabular}

Veriler ortanca (min-maks) olarak verilmiştir. ${ }^{\star} \mathrm{p}<0,05$ kontrol grubuna göre, \& $\mathrm{p}<0,05$ diyabet grubuna göre, $\#$ p $<0,05$ kontrol+mel grubuna göre farklılı̆̆ göstermektedir.

Tablo 2. İskelet ve kalp kası GSH düzeyleri.

\begin{tabular}{lccccc}
\hline & Kontrol & Kontrol+Mel & Diyabet & Diyabet+Mel & p \\
\hline \multirow{2}{*}{ İskelet Kası GSH mikromol/g doku } & 4,35 & $4,95^{*}$ & $4 \#$ & $3,9 \#$ & \multirow{2}{*}{$\mathbf{0 , 0 0 1}$} \\
\hline \multirow{2}{*}{ Kalp Kası GSH mikromol/g doku } & $(4,2-4,4)$ & $(4,8-5,5)$ & $(3,9-4,2)$ & $(3,8-4,1)$ & $\begin{array}{c}4,7 \\
\end{array}$ \\
\hline
\end{tabular}

Veriler ortanca (min-maks) olarak verilmiştir. ${ }^{*} \mathrm{p}<0,05$ kontrol grubuna göre, $\& \mathrm{p}<0,05$ diyabet grubuna göre, $\# \mathrm{p}<0,05$ kontrol+mel grubuna göre farklılığ1 göstermektedir

Tablo 3. İskelet ve kalp kası Nrf2 düzeyleri.

\begin{tabular}{lccccc}
\hline & Kontrol & Kontrol+Mel & Diyabet & Diyabet+Mel & p \\
\hline \multirow{2}{*}{ İskelet Kası Nrf2 ng/ml doku } & 12,2 & 11,4 & $8,55^{*} \#$ & $13,5 \&$ & \multirow{2}{*}{ \& } \\
& $(11,4-12,2)$ & $(11,1-11,9)$ & $(8-9,9)$ & $(13,3-13,9)$ & $\mathbf{0 0 1}$ \\
\hline \multirow{2}{*}{ Kalp Kası Nrf2 ng/ml doku } & 9,1 & 8,15 & 8 & $9,6 \&$ & $\mathbf{0 , 0 0 1}$ \\
\hline
\end{tabular}

Veriler ortanca (min-maks) olarak verilmiştir. ${ }^{\star} \mathrm{p}<0.05$ kontrol grubuna göre, $\& \mathrm{p}<0.05$ diyabet grubuna göre, \# $\mathrm{p}<0.05$ kontrol+mel grubuna göre farklılığı göstermektedir.

Tablo 4. İskelet ve kalp kası Trx düzeyleri.

\begin{tabular}{lccccc}
\hline & Kontrol & Kontrol+Mel & Diyabet & Diyabet+Mel & p \\
\hline \multirow{2}{*}{ İskelet Kası Trx ng/ml doku } & 24,75 & 26,6 & 24,75 & 27,25 & 0,065 \\
\hline \multirow{2}{*}{ Kalp Kası Trx ng/ml doku } & $(22-26)$ & $(23,9-29)$ & $(24-27,4)$ & $(25,1-29,5)$ & 0,05 \\
& 23,1 & 21,35 & $16,55^{*} \#$ & $27,5^{*} \# \&$ & \multirow{2}{*}{$\mathbf{0 , 0 0 1}$} \\
\hline
\end{tabular}

Veriler ortanca (min-maks) olarak verilmiştir. ${ }^{*} \mathrm{p}<0.05$ kontrol grubuna göre, $\& \mathrm{p}<0.05$ diyabet grubuna göre, $\# \mathrm{p}<0.05$ kontrol+mel grubuna göre farklılığı göstermektedir. 
azalma engellenebilmiştir. TRX düzeyi diyabette kalp kasında azalırken, melatonin tedavisi ile normal düzeylere gelebilmiştir ancak iskelet kasında herhangi bir farklılık saptanmamıştır.

DM hiperglisemi ile karakterizedir ve diyabetik retinopati, diyabetik nefropati, diyabetik nöropati ve miyopati ile diyabetik kardiyomiyopati gibi komplikasyonlara yol açmaktadır. Bunlar arasında diyabetik kardiyomiyopati yüksek mortalite ve morbiditeye neden olan majör komplikasyondur (17). Diyabette insülin salınımı veya fonksiyonundaki bozukluk sebebiyle ya da her iki durumun birlikte olmasıyla ortaya çıkan hiperglisemik ortam, kalp ve iskelet kası da dahil olmak üzere birçok organı olumsuz etkiler ( 9 , 18). Hiperglisemik ortam sonucu aşırı ROS üretiminin yol açtı̆̆ kalp kası dokusundaki nekroz, apoptoz, fibrosiz ve inflamasyon, kalp kasında yapisal ve fonksiyonel bozukluklar meydana getirmektedir (19). Ayrıca diyabetin kollajen oluşumuyla beraber fibrozise, miyokard kontraktil proteinlerinde ve hücresel kalsiyum metabolizmasında anormalliklere, mitokondriyal disfonksiyona, endoplazmik retikulum stresine, anormal koroner dolaşıma, sempatik sinir sistemi ve renin anjiotensin aldosteron sisteminin aktivasyonuna neden olarak miyokard hücrelerinde çeşitli sinyal yolaklarını bozduğu gösterilmiştir. Bu patofizyolojik değişiklikler kardiyomiyositlerde harabiyete neden olmaktadır (20-22). Deneysel diyabet modelleri de insan diyabetik kardiyomiyopati patofizyolojisini yansitan metabolik, yapisal ve fonksiyonel problemleri sergilemektedir (23). DM, ayrica kas kitle ve fonksiyonlarının bozulduğu diyabetik miyopatiye neden olmaktadır. Sıklıkla göz ardı edilen bu komplikasyon iskelet kasının glukoz homeostazisindeki rolünden dolayı diğer diyabetik komplikasyonların oluşmasına aracılık etmektedir. Ancak hâlâ diyabetik miyopatiyi tetikleyici mekanizmalar tam olarak açıklanamamıștır (24).

Miyosit hasarındaki en önemli etkenlerden biri diyabetteki artmış SOR üretimidir. Fazla SOR üretimi membran proteinleri, lipidleri ve nükleik asitlerle reaksiyona girmekte ve hücrenin ölümüne kadar giden bir süreci başlatmaktadır. Lipid peroksidasyonunun son ürünü MDA olarakbilinmekte ve oksidatif stres için önemli bir belirteç olarak kabul edilmektedir (25). Çalışmamızda diyabet hem iskelet kasında hem de kalp kasında MDA düzeylerinin yükselmesine neden olmuştur. Yani diyabet ile oksidatif stres artışı her iki dokuyu da etkilemiştir. Literatürde diyabetin MDA artışına neden olduğunu gösteren pek çok çalışma bulunmaktadır ve bu yönüyle çalışmamız literatürü desteklemektedir. Yapılan in vivo bir çalışmada kontrol grubuyla karşılaştırıldığında diyabet grubunda MDA seviyesi yüksek ve GSH seviyesi düşük bulunmuştur (26). Diğer bir çalışmada serum MDA seviyesi DM hastalarında sağlıklı gruba göre daha yüksek bulunmuştur. Aynı çalışmada MDA seviyelerindeki düşüş ile total antioksidan kapasitedeki artış arasında güçlü bir korelasyon görülmüştür (27).

Melatonin ve türevleri, SOR detoksifikasyonu ile birlikte moleküler hasarı azaltıcı antioksidan bir rol oynar $(28,29)$. Melatonin amfifilik özelliği sayesinde fizyolojik bariyerlerden kolayca geçer ve diğer antioksidanlara göre daha geniş bir etki alanı vardır (30). Diyabette artan MDA düzeylerinin melatonin uygulaması ile beyin, akciğer, kemik, retina gibi birçok dokuda azaldığı gösterilmiştir (31-33). Çalışmamızda 4 hafta süresince melatonin tedavisi iskelet ve kalp kasında MDA düzeylerini azaltmıştır. $\mathrm{Bu}$ bulgu melatoninin iyi bilinen antioksidan özelliğini destekler niteliktedir.

Melatoninin bir antioksidan olarak etkilerinin yanı sıra antioksidan enzimlerin aktivitelerini uyarıcı etkisiyle de antioksidan sisteme katkı sağlar (34). Bununla birlikte oksidatif strese hangi mekanizmayla karşı koyduğu hâlâ tam olarak net değildir. Nrf2, hücreleri çeşitli antioksidan genleri ve enzimleri aktive ederek SOR gibi streslere karşı korur (35). İskelet kası bütünlüğü, lif tipi ve mitokondriyal biyogenezde önemli bir değişiklik olmamasına rağmen, Nrf2 eksikliğinin mitokondriyal solunumu olumsuz etkilediği görülmüștür (36). Çalışmamızda diyabetin iskelet kas dokusunda Nrf2 seviyelerini azaltması diyabetin iskelet kası ile ilgili komplikasyonlarının oluşumunu artıracağını düşündürmektedir. Ayrıca melatonin uygulaması ile azalan NRF2 düzeyleri tekrar normal seviyelere yükselmiştir. Shi ve ark. (37) böbrek iskemisi yapılan diyabetik sıçanlarda azalan Nrf2 seviyesinin melatonin tedavisiyle yükseldiğini göstermişlerdir. Diyabetik retinopati yapılan ratlarda 8 ve 12 haftalık melatonin tedavisinin diyabet ile azalan Nrf2 düzeylerini kontrol seviyelerine getirdiği başka bir çalışmada gösterilmiştir (14). Negi ve ark. (38) diyabetik nöropati oluşturdukları ratlarda gelişen nöroinflamasyonun, melatonin uygulandığında hemoksijenaz-1 ekspresyonlarını artırarak Nrf2 yolağını düzenlediğini bildirmişlerdir. Çalışmamız farklı dokularda Nrf2 üzerine etkisi gösterilen melatoninin iskelet kasında da benzer bir etki ortaya çıkarttığı yönündedir. Bu etki, melatonin tedavisi ile iskelet kasında lipid peroksidasyonunun azalmış olmasının, melatoninin Nrf2 üzerindeki düzenleyici etkisinden kaynaklandığını düşündürmektedir.

Diyabetik ve vahşi tip fareler ile yapılan bir çalışmada, normal ve diyabetik kardiyomiyositlerde Nrf2'nin ROS üretimi ve apoptoza karşı savunmada önemli bir düzenleyici olduğu belirtilmiştir (39). Melatonin uygulamasının beyin hasarı ve diyabetik nöropatide, Nrf2 aktivasyonu ile koruyucu etkisi gösterilmiştir $(38,40)$. Çalışmamızda diyabet grubunda kalp kası Nrf2 düzeyleri kontrol grubuna göre düşük bulunsa da bu farklılık anlamlı bulunmamıştır. 
Diyabette melatonin kullanımı Nrf2 düzeylerini artırmıştır. Zhang ve ark. (41) iskemi reperfüzyon hasarı oluşturdukları kardiyomiyositlerde melatoninin Nrf2 yolağını aktive ederek oksidatif stresi ve apoptozisi engellediğini ve miyositleri koruduğunu göstermişlerdir. Yapılan başka bir çalışmada kalp yetmezliği oluşturulan farelerde melatoninin Nrf2 yolağ1 aracılığıyla koruyucu olduğu bildirilmiştir (42). Çalışmamızda diyabette melatonin tedavisiyle Nrf2 düzeylerinin artmış olması melatoninin Nrf2 yolağ1 ile diyabette de koruyucu etkili olduğunu göstermesi açısından önemlidir.

Diyabet durumlarında oksidan/antioksidan denge bozulur ve fazla miktarda ROS üretimi diyabetik komplikasyonların gelişmesini hızlandırır (43). Bu durumu engellemek için antioksidan sistemin aktive olması gerekmektedir. TRX, nörodejeneratif hastalıklarda koruyuculuğu gösterilen, apoptozisi engelleyici özelliği olan ve lipid peroksidasyonunu önleyici rolü ile bilinen antioksidan ailesinin bir üyesidir (44). GSH'da vücutta endojen olarak bulunan önemli bir antioksidandır. STZ ile diyabet oluşturulmuş rat kalplerinde TRX ve GSH seviyelerinin azaldığ bildirilmiştir (43). Aynı şekilde diyabet olușturulmuş rat aortasında hipergliseminin TRX seviyelerini azalttığı bilinmektedir (45). Miyokardial iskemi reperfüzyon modeli oluşturulan bir çalışmada melatoninin TRX sistemini aktive ederek TRX etkileşimli proteinin ekspresyonunu baskılayarak oksidatif stresi azalttığı gösterilmiştir (46). Biz de çalışmamızda diyabet oluşturulan ratların kalp kası TRX seviyelerinde azalma saptadık. Melatonin uygulaması ile azalan TRX seviyeleri normal seviyelere yükseldi. Melatonin kalp kasında antioksidan etkisini TRX seviyelerini artırarak göstermiştir. Çalışmamızda grupların iskelet kas TRX seviyelerinde anlamlılık saptanmadı. Bu bize melatoninin iskelet kasında farklı antioksidan yolakları kullanarak oksidatif stresi azalttığını düşündürmektedir. Çalışmamızda ayrıca diyabetli grupların iskelet kasında GSH seviyeleri düşüktür. Melatonin uygulaması diyabetli grubun iskelet kasında GSH seviyelerini değiştirmemiştir.

Sonuç olarak melatonin, diyabette özellikle kalp ve iskelet kasında ortaya çıkan hasarların önlenmesinde tedavi edici bir ajan olabilir. Ancak bu koruyucu etkinin altında yatan patofizyolojik mekanizmaların açıklanması için daha ayrıntılı çalışmalara ihtiyaç bulunmaktadır.

\section{Finansal Destek}

Bu çalışma Zonguldak Bülent Ecevit Üniversitesi Bilimsel Araştırma Projeleri Koordinasyon Birimi tarafından desteklenmiştir (BAP No: 2016-26259946-02).

\section{Çıkar Çatıșması}

Yazarlar arasında herhangi bir çıkar çatışması yoktur.

Yazarların Makaleye Katkı Beyanı

Deneysel prosedürlerin uygulanması: Salim Özenoğlu, Deneysel prosedürlerin uygulanması, verilerin toplanması, makale yazımı: İnci Turan, Deneysel prosedürlerin uygulanması, verilerin analizi: Hale Sayan Özaçmak, Verilerin analizi, makale yazımı: V. Haktan Özaçmak.

\section{KAYNAKLAR}

1. Mollazadeh H, Sadeghnia HR, Hoseini A, Farzadnia M, et al. Effects of pomegranate seed oil on oxidative stress markers, serum biochemical parameters and pathological findings in kidney and heart of streptozotocin-induced diabetic rats. Ren Fail. 2016;38(8):1256-1266.

2. Tian X, Liu Y2 Ren G, Yin L, Liang X, et al. Resveratrol limits diabetes-associated cognitive decline in rats by preventing oxidative stress and inflammation and modulating hippocampal structural synaptic plasticity. Brain Res. 2016;1650:1-9.

3. Yang H, Mao Y, Tan B, Luo S, Zhu Y. The protective effects of endogenous hydrogen sulfide modulator, S-propargylcysteine, on high glucose-induced apoptosis in cardiomyocytes: A novel mechanism mediated by the activation of Nrf2. Eur J Pharmacol. 2015;761:135-143.

4. Chen J, Zhang Z, Cai L. Diabetic cardiomyopathy and its prevention by Nrf2: Current status. Diabetes Metab J. 2014;38(5):337-345.

5. Guan Y, Cui ZJ, Sun B, Han LP, et al. Celastrol attenuates oxidative stress in the skeletal muscle of diabetic rats by regulating the AMPK-PGCla-SIRT3 signaling pathway. Int J Mol Med. 2016;37(5):1229-1238.

6. Cappellari GG, Zanetti M, Semolic A, Vinci P, Ruozi G, et al. Unacylated ghrelin reduces skeletal muscle reactive oxygen species generation and inflammation and prevents high-fat diet-induced hyperglycemia and whole-body insulin resistance in rodents. Diabetes. 2016;65(4):874-886.

7. Boden MJ, Brandon AE, Tid-Ang JD, Preston E, Wilks D, et al. Overexpression of manganese superoxide dismutase ameliorates high-fat diet-induced insulin resistance in rat skeletal muscle. Am J Physiol Metab. 2012;303(6):E798-805.

8. Wu $\mathrm{H}$, Ballantyne CM. Skeletal muscle inflammation and insulin resistance in obesity. J Clin Invest. 2017;127(1):43-54.

9. D'Souza DM, Al-Sajee D, Hawke TJ. Diabetic myopathy: Impact of diabetes mellitus on skeletal muscle progenitor cells. Front Physiol. 2013;4:379.

10. Liu YW, Cheng YQ, Liu XL, et al. Mangiferin upregulates glyoxalase 1 through activation of Nrf2/ARE signaling in central neurons cultured with high glucose. Mol Neurobiol. 2017;54(6):4060-4070. 
11. Sun Q, Shen ZY, Meng QT, Liu HZ, et al. The role of DJ-1/Nrf2 pathway in the pathogenesis of diabetic nephropathy in rats. Ren Fail. 2016;38(2):294-304.

12. Reiter RJ, Mayo JC, Tan DX, Sainz RM, et al. Melatonin as an antioxidant: Under promises but over delivers. J Pineal Res. 2016;61(3):253-278.

13. Teodoro BG, Baraldi FG, Sampaio IH, Bomfim LH, Queiroz $\mathrm{AL}$, et al. Melatonin prevents mitochondrial dysfunction and insulin resistance in rat skeletal muscle. J Pineal Res. 2014;57(2):155-167.

14. Jiang T, Chang Q, Cai J, Fan J, et al. Protective effects of melatonin on retinal inflammation and oxidative stress in experimental diabetic retinopathy. Oxid Med Cell Longev. 2016;2016:1-13.

15. Casini AF, Ferrali M, Pompella A, Maellaro E, Comporti M. Lipid peroxidation and cellular damage in extrahepatic tissues of bromobenzene-intoxicated mice. Am J Pathol. 1986;123(3):520-531.

16. Aykaç G, Uysal M, Yalçin AS, Koçak-Toker N, et al. The effect of chronic ethanol ingestion on hepatic lipid peroxide, glutathione, glutathione peroxidase and glutathione transferase in rats. Toxicology. 1986;36(1):71-76.

17. Meng S, Yang F, Wang Y, Qin Y, et al. Silymarin ameliorates diabetic cardiomyopathy via inhibiting TGF- $\beta 1 / \mathrm{Smad}$ signaling. Cell Biol Int. 2019; 3(1):65-72.

18. Marwick TH, Ritchie R, Shaw JE, et al. Implications of underlying mechanisms for the recognition and management of diabetic cardiomyopathy. J Am Coll Cardiol. 2018;71(3):339351.

19. Ge ZD, Lian Q, Mao X, Xia Z. Current status and challenges of NRF2 as a potential therapeutic target for diabetic cardiomyopathy. Int Heart J. 2019;60(3):512-520.

20. Trachanas K, Sideris S, Aggeli C, Poulidakis E, et al. Diabetic cardiomyopathy: From pathophysiology to treatment. Hellenic J Cardiol. 2014;55(5): 411-421.

21. Kandemir Y, Tosun V, Güntekin Ü. Melatonin protects against streptozotocin-induced diabetic cardiomyopathy through the mammalian target of rapamycin (mTOR) signaling pathway. Adv Clin Exp Med. 2019;28(9):1171-1177.

22. Jia G, DeMarco VG, Sowers JR. Insulin resistance and hyperinsulinaemia in diabetic cardiomyopathy. Nat Rev Endocrinol. 2016;12(3):144-153.

23. Fuentes-Antras J, Picatoste B, Gómez-Hernández A, et al. Updating experimental models of diabetic cardiomyopathy. J Diabetes Res. 2015:656795.

24. Hernández-Ochoa EO, Llanos P, Lanner JT. The underlying mechanisms of diabetic myopathy. J Diabetes Res. 2017;2017:7485738.

25. Maritim AC, Sanders RA, Watkins JB 3rd. Diabetes, oxidative stress, and antioxidants: A review. J Biochem Mol Toxicol 2003;17(1):24-38.

26. Soliman GZ. Blood lipid peroxidation (superoxide dismutase, malondialdehyde, glutathione) levels in Egyptian type 2 diabetic patients. Singapore Med J. 2008;49(2):129-136.
27. Armstrong AM, Chestnutt JE, Gormley MJ, Young IS. The effect of dietary treatment on lipid peroxidation and antioxidant status in newly diagnosed noninsulin dependent diabetes. Free Radic Biol Med. 1996;21(5):719-726.

28. Tan DX, Manchester LC, Esteban-Zubero E, et al. Melatonin as a potent and inducible endogenous antioxidant: Synthesis and metabolism. Molecules. 2015;20(10):18886-18906.

29. Reiter RJ, Paredes SD, Manchester LC, Tan DX. Reducing oxidative/nitrosative stress: A newly-discovered genre for melatonin melatonin as an antioxidant. Crit Rev Biochem Mol Biol. 2009;44(4):175-200.

30. Bonnefont-Rousselot D, Collin F. Melatonin: Action as antioxidant and potential applications in human disease and aging. Toxicology. 2010;278(1):55-67.

31. Onk D, Onk OA, Erol HS, Özkaraca M, et al. Effect of melatonin on antioxidant capacity, inflammation and apoptotic cell death in lung tissue of diabetic rats. Acta Cir Bras. 2018;33(4):375385.

32. Bicer M, Baltaci SB, Patlar S, Mogulkoc R, Baltaci AK. Melatonin has a protective effect against lipid peroxidation in the bone tissue of diabetic rats subjected to acute swimming exercise. Horm Mol Biol Clin Investig. 2018;34(2).

33. Mehrzadi S, Motevalian M, Rezaei Kanavi M, Fatemi I, et al. Protective effect of melatonin in the diabetic rat retina. Fundam Clin Pharmacol 2018;32(4):414-421.

34. Rodriguez C, Mayo JC, Sainz RM, Antolín I, et al. Regulation of antioxidant enzymes: A significant role for melatonin. J Pineal Res. 2004;36(1):1-9.

35. Uruno A, Yagishita Y, Yamamoto M. The Keap1-Nrf2 system and diabetes mellitus. Arch Biochem Biophys. 2015;566:76-84.

36. Coleman V, Sa-Nguanmoo P, Koenig J, Schulz TJ, et al. Partial involvement of Nrf2 in skeletal muscle mitohormesis as an adaptive response to mitochondrial uncoupling. Sci Rep. 2018;8(1):2446.

37. Shi S, Lei S, Tang C, Wang K, Xia Z. Melatonin attenuates acute kidney ischemia/reperfusion injury in diabetic rats by activation of the SIRT1/Nrf2/HO-1 signaling pathway. Biosci Rep. 2019;39(1):BSR20181614.

38. Negi G, Kumar A, Sharma SS. Melatonin modulates neuroinflammation and oxidative stress in experimental diabetic neuropathy: Effects on NF- $\kappa \mathrm{B}$ and Nrf2 cascades. J Pineal Res. 2011;50(2):124-131.

39. He X, Kan H, Cai L, Ma Q. Nrf2 is critical in defense against high glucose-induced oxidative damage in cardiomyocytes. J Mol Cell Cardiol. 2009;46(1):47-58.

40. Ding K, Wang H, Xu J, Li T, et al. Melatonin stimulates antioxidant enzymes and reduces oxidative stress in experimental traumatic brain injury: The Nrf2-ARE signaling pathway as a potential mechanism. Free Radic Biol Med. 2014;73:1-11.

41. Zhang Y, Qiao B, Gao F, Wang H, et al. Melatonin protects H9c2 cells against ischemia/reperfusion-induced apoptosis and oxidative stress via activation of the Nrf2 signaling pathway. Mol Med Rep. 2018;18(3): 3497-3505. 
42. Liu Y, Li LN, Guo S, Zhao XY, Liu YZ, et al. Melatonin improves cardiac function in a mouse model of heart failure with preserved ejection fraction. Redox Biol. 2018;18:211-221.

43. Okatan EN, Tuncay E, Turan B. Cardioprotective effect of selenium via modulation of cardiac ryanodine receptor calcium release channels in diabetic rat cardiomyocytes through thioredoxin system. J Nutr Biochem. 2013;24(12):2110-2118.

44. Li H, Xu C, Li Q, Gao X, Sugano E, et al. Thioredoxin 2 offers protection against mitochondrial oxidative stress in H9c2 cells and against myocardial hypertrophy induced by hyperglycemia. Int J Mol Sci. 2017;18(9):1958.
45. Schulze PC, Yoshioka J, Takahashi T, He Z, et al. Hyperglycemia promotes oxidative stress through inhibition of thioredoxin function by thioredoxin-interacting protein. J Biol Chem. 2004;279(29):30369-30374.

46. Yu L, Fan C, Li Z, Zhang J, Xue X, et al. Melatonin rescues cardiac thioredoxin system during ischemia-reperfusion injury in acute hyperglycemic state by restoring Notch1/Hes1/ Akt signaling in a membrane receptor-dependent manner. J Pineal Res. 2017;62(1):e12375. 